(C) 2022, The Authors. Published by Elsevier Inc. and Fass Inc. on behalf of the American Dairy Science Association ${ }^{\circledR}$. This is an open access article under the CC BY license (http://creativecommons.org/licenses/by/4.0/).

\title{
Bactericidal and antibiofilm properties of Rumex japonicus Houtt. on multidrug-resistant Staphylococcus aureus isolated from milk
}

\author{
G. Kim, ${ }^{1} \oplus$ Y. J. Xu, ${ }^{1}$ A. K. Farha,${ }^{1}$ Z. Q. Sui, ${ }^{1 *}$ and H. Corke ${ }^{2,3 *}$ \\ ${ }^{1}$ Department of Food Science and Technology, Shanghai Jiao Tong University, Shanghai 200240, China \\ ${ }^{2}$ Biotechnology and Food Engineering Program, Guangdong Technion-Israel Institute of Technology, Shantou 515063, China \\ ${ }^{3}$ Faculty of Biotechnology and Food Engineering, Technion-Israel Institute of Technology, Haifa 3200003, Israel
}

\begin{abstract}
Multidrug-resistant (MDR) Staphylococcus aureus and its biofilm formation have been challenging to control in milk and dairy industries. Biofilms formed by Staph. aureus may result in the failure of antibacterial agents and disinfectants to penetrate the biofilm in an attempt to control contamination. Novel natural antibacterial agents are required to combat MDR bacteria and biofilms. In this study, we evaluated the bactericidal, antibiofilm, and antimotility effects of Rumex japonicus Houtt. (RJH) extract on MDR Staph. aureus isolated from milk. The RJH extract exhibited good antibacterial activity against MDR strains with minimum inhibitory concentrations (MIC) ranging from 0.78 to $6.25 \mathrm{mg} / \mathrm{mL}$ and minimum bactericidal concentrations ranging from 3.125 to $12.5 \mathrm{mg} / \mathrm{mL}$. The extract showed strong inhibition of biofilm formation (81.9\%) at sub-MIC value and eradication of biofilm at higher concentrations. The motility of Staph. aureus was effectively blocked by the extract. Major compounds emodin, chrysophanol, and physcion were identified in RJH extract using HPLC-linear trap quadrupole (LTQ)/Orbitrap-mass spectrometry. The extract was nontoxic to human epithelial cell lines such as Caco-2 and HT-29 cell lines at concentrations ranging from 0.1 to $0.5 \mathrm{mg} / \mathrm{mL}$, and from 0.1 to $0.75 \mathrm{mg} / \mathrm{mL}$, respectively. These findings suggest that RJH extract could be an alternative to synthetic preservatives in milk and dairy products.
\end{abstract}

Key words: multidrug resistance, Rumex japonicus, antibacterial activity, antiviral effect, natural preservative

Received August 30, 2021.

Accepted November 12, 2021.

*Corresponding authors: zsui@sjtu.edu.cn and hcorke@yahoo.com

\section{INTRODUCTION}

Staphylococcus aureus is one of the major foodborne pathogens worldwide, and its associated food poisoning is attributed to strong virulence factors such as the production of toxins, biofilms, and various resistance proteins (Jørgensen et al., 2005; Kümmel et al., 2016). The major symptoms of Staph. aureus infection are associated with gastrointestinal illness such as vomiting, diarrhea, and stomach cramps (Johler et al., 2015; Kümmel et al., 2016). According to the United States Centers for Disease Control, approximately 240,000 cases of Staph. aureus are reported annually in the United States, including 1,681 cases of illness and 86 cases of hospitalization (Higginbotham et al., 2014; Johler et al., 2015; Babić et al., 2019). Although it accounts for a small percentage of total food poisoning illnesses, there are still serious problems due to the emergence of multidrug resistance (MDR). The outbreak of staphylococcal food poisoning is mainly associated with consumption of contaminated foods including meat, dairy, bakery products, and other animal-derived foods (Hennekinne et al., 2012). Milk, especially raw milk, is often contaminated with Staph. aureus from dairy animals with subclinical mastitis (Aslantaş and Demir, 2016; Felipe et al., 2019). Additionally, low level of viable Staph. aureus cells might be still present in pasteurized and UHT milks and other dairy products due to inadequate processing or handling, leading to economic loss and potential risks to public health (Hennekinne et al., 2012; Chen et al., 2020a).

The emergence of MDR Staph. aureus is a global problem in food safety. The indiscriminate use of antibacterial agents in agricultural and food industries causes the development of MDR bacteria, which are attributed to the alteration of the drug target site, horizontal gene transfer, acquisition of new resistance genes through mobile genetic elements, and impermeability of antibiotics into bacterial biofilm (Aminov 2009; Munita and Arias, 2016). Staphylococcus aureus is a highly virulent pathogen that is capable of forming biofilms on 
a variety of abiotic or biotic surfaces (Lister and Horswill, 2014). Forming biofilm is an important strategy for bacterial survival under unfavorable environments, such as osmotic stress, nutrient scarcity, mechanical and thermal forces, as well as exposure to antimicrobial agents (Frank and Koffi, 1990). The biofilm is a microbial aggregate embedded in a self-produced matrix. It consists of extracellular polymeric substances, including proteins, nucleic acids, and polysaccharides, and provides a physical barrier to the penetration of antibacterial agents and disinfectants (Lister and Horswill, 2014). Moreover, the biofilm can facilitate the emergence and spread of heritable MDR (Ogawara, 2019).

In the milk and dairy industries, it is challenging to control the MDR Staph. aureus and its biofilms, leading to serious economic losses. In our previous study, we found that Staph. aureus strains isolated from milk have MDR to erythromycin, ciprofloxacin, clindamycin, gentamicin, penicillin, and streptomycin (Zhang et al., 2019). Some synthetic chemicals such as sodium azide have been used to inhibit the growth of Staph. aureus, although there are still concerns about undesirable side effects of these chemicals (Upadhyay et al., 2014; Alfaifi et al., 2020). In addition, these available antimicrobial agents have limited efficacy against MDR bacteria (Gatadi et al., 2019). In the case of thermal processing to control pathogens, there is also potential damage to the nutritional and sensory properties of milk and dairy products by overpasteurization (Chen et al., 2020a).

Plant-derived antimicrobials have received attention as a promising alternative for the development of new preservatives due to their antibacterial properties and safety (Ma et al., 2018). The plant extracts have multitargeted inhibitory effects such as cellular mechanism, disturbance of cell membranes, and modulation of virulence factors, contributing a broad spectrum of antibacterial activity against MDR pathogens (Gyawali and Ibrahim, 2014; Silva et al., 2016). Rumex japonicus Houtt. (RJH) belongs to the Polygonaceae family, and it contains a variety of phytochemical constituents, including anthraquinones, phenolic compounds, flavonoids, and triterpenoids (Sun et al., 2020). With various chemical scaffolds and complex structures, these phytochemicals in RJH could potentiate its antibacterial activity against MDR bacteria (Gyawali and Ibrahim, 2014).

This present study was carried out to examine virulence factors of Staph. aureus isolates from milk and to investigate bactericidal and antivirulence effects of RJH extract on MDR Staph. aureus. To the best of our knowledge, we are the first to report that hydroethanolic RJH extract has antibacterial and antivirulence effects and is applicable in a food matrix. In addition, we identified the phytochemical compounds present in RJH extract and evaluated the cytotoxicity of RJH extract on human colon epithelial cell lines. This study suggested that RJH extract is a promising biopreservative with activity against MDR Staph. aureus.

\section{MATERIALS AND METHODS}

\section{Plant Material and Extraction}

Rumex japonicus Houtt. was collected from a market in Shanghai, China. The dried roots were ground into powder using a laboratory-scale mill (S025, IKA). Powder $(4.0 \mathrm{~g})$ was extracted twice with $40 \mathrm{~mL}$ of $60 \%$ (vol/vol) ethanol using an ultrasound-assisted extraction method $\left(1 \mathrm{~h}, 40^{\circ} \mathrm{C}\right.$, and $\left.480 \mathrm{~W}\right)$. The extract was centrifuged at room temperature $(900 \times g, 15 \mathrm{~min})$ and the supernatant concentrated using a rotary evaporator (Shanghai Ya Rong Co. Ltd.) at $40^{\circ} \mathrm{C}$ under vacuum. The concentrated extract was dried using a vacuum freeze-dryer (Ningbo Shuang Jia instrument Co., Ltd.). The freeze-dried extract was dissolved in 1\% dimethyl sulfoxide (Beyotime) for further use.

\section{Qualitative Analysis by HPLC-Linear Trap Quadrupole/Orbitrap-MS}

The HPLC analyses were performed on a HPLC 1260 system (Agilent) equipped with quaternary pump, an autosampler, a thermostatically controlled column compartment, and a vacuum degasser unit. The RJH extract $(20 \mu \mathrm{L})$ dissolved in methanol $(15 \mathrm{mg} / \mathrm{mL})$ was injected into an HPLC column (C18 $5 \mu \mathrm{m}, 4.6 \times 250$ $\mathrm{mm}$; Shimadzu) at a flow rate of $1 \mathrm{~mL} / \mathrm{min}$ in $70 \mathrm{~min}$ from $30 \%$ methanol and $70 \% \mathrm{H}_{2} \mathrm{O}(0.1 \%$ formic acid $)$ to $90 \%$ methanol and $10 \% \mathrm{H}_{2} \mathrm{O}$ (0.1\% formic acid) at $35^{\circ} \mathrm{C}$. A hybrid linear trap quadrupole (LTQ)-orbitrap XL MS (Thermo Fisher Scientific) was connected to an HPLC system equipped with a binary pump and an autosampler (Thermo Fisher Scientific) via an electrospray ionization (ESI) interface in a post-column splitting ratio of 1:4. For MS detection, high-purity nitrogen $\left(\mathrm{N}_{2}\right)$ was used as the sheath gas and auxiliary gas, and ultra-high pure helium (He) was used as the collision gas. The optimized ESI parameters in the positive and negative ion modes were as follows: resolution of the orbitrap mass analyzer was set as 30,000; capillary temperature was $320^{\circ} \mathrm{C}$; sheath gas flow was 35 arbitrary units (arb.); auxiliary gas flow was 20 arb.; source voltage was $4.0 \mathrm{kV}$; capillary voltage was $24 \mathrm{~V}$; tube lens voltage was $65 \mathrm{~V}$. The analysis was performed in both negative and positive ion mode with the mass range of $\mathrm{m} / z 50$ to 2,000 . The MS full scan was detected by high-resolution and MS/MS analysis by an ion trap 
dynode. The MS scan functions and HPLC solvent gradients were controlled by the Xcalibur data system (Thermo Scientific), and all the data acquisition and processing were conducted by Xcalibur 2.1 software (Thermo Scientific).

\section{Bacterial Strains and Culture Conditions}

A total of 11 isolates of Staph. aureus from milk were used in the study. Staphylococcus aureus ATCC 25923 was used as the reference strain. The isolates were evaluated for the antibiotic sensitivity in our previous study (Zhang et al., 2019). All bacterial strains were grown at $37^{\circ} \mathrm{C}$ in tryptic soy broth (TSB; Oxoid).

\section{Biofilm Formation}

The biofilm-forming ability of Staph. aureus strains was evaluated as described by Ackerman et al. (2018) with modifications. Briefly, $100 \mu \mathrm{L}$ of bacterial suspension in TSB supplemented with $1 \%$ glucose $\left(1 \times 10^{6}\right.$ $\mathrm{cfu} / \mathrm{mL}$ ) was added into each well of 96 -well microtiter plate (Corning). After $24 \mathrm{~h}$ of incubation, planktonic cells in each well were removed. Then, wells were gently washed with PBS (pH 7.5) twice, air dried, and stained with $0.1 \%$ crystal violet (Aladdin) for 5 min. Excess crystal violet was removed by washing with PBS 3 times. Then, 33\% (vol/vol) glacial acetic acid (SigmaAldrich) was used to dissolve the precipitates in wells. The biofilm was quantified by measuring absorbance at $595 \mathrm{~nm}$ using a microtiter reader (Molecular Devices). The biofilm-forming ability of strains was categorized by comparing optical density (OD) value of each strain with that of the negative control $\left(\mathrm{OD}_{\mathrm{NC}}\right)$, as follows: weak $\left(\mathrm{OD}_{\mathrm{NC}}<\mathrm{OD} \leq 2 \times \mathrm{OD}_{\mathrm{NC}}\right)$, moderate $(2 \times$ $\left.\mathrm{OD}_{\mathrm{NC}}<\mathrm{OD} \leq 4 \times \mathrm{OD}_{\mathrm{NC}}\right)$, or strong $\left(\mathrm{OD}>4 \times \mathrm{OD}_{\mathrm{NC}}\right)$ biofilm producers (Lee et al., 2014).

\section{Motility}

Motility of Staph. aureus strains was evaluated according to a previous study (O'May and Tufenkji, 2011). An overnight culture of Staph. aureus $(5 \mu \mathrm{L})$ was inoculated onto the center of the TSB plates containing $0.25 \%$ agar. The plates were incubated at $37^{\circ} \mathrm{C}$ for 24 $\mathrm{h}$, and the zones of motility were observed.

\section{Antibacterial Activity}

Determination of MIC and Minimum Bactericidal Concentration. The MIC and minimum bacterial concentration (MBC) of RJH extract against Staph. aureus isolates were determined by a serial di- lution microplate method and Mueller-Hinton (MH) agar counting, respectively (Kim et al., 2020).

Time-Kill Analysis. To evaluate the antibacterial activity of RJH extract against Staph. aureus strains, time-kill analysis was conducted. Staphylococcus aureus ATCC 25923, SJTUF 20745, SJTUF 20758, and SJTUF $20841\left(1 \times 10^{6} \mathrm{cfu} / \mathrm{mL}\right)$ at the exponential phase were cultured in $\mathrm{MH}$ broth (Oxoid) supplemented with various concentrations of the extract $(1 / 8 \mathrm{MIC}, 1 / 4 \mathrm{MIC}$, $1 / 2 \mathrm{MIC}, \mathrm{MIC}$, and $\mathrm{MBC})$ at $37^{\circ} \mathrm{C}$ with shaking at $180 \mathrm{rpm}$ for $24 \mathrm{~h}$ in an incubator. Aliquots were taken at different time intervals $(0,2,4,8,12$, and $24 \mathrm{~h})$, and viable bacterial colonies were counted by plating aliquots on $\mathrm{MH}$ agar.

Nucleic Acid and Protein Leakage Assay. Cytoplasmic components such as nucleic acids and proteins released from bacterial cells after extract treatment were analyzed to evaluate the integrity of the cell membrane (Chen et al., 2020b). Exponential growth phase cells of Staph. aureus strains ATCC 25923, SJTUF 20745, SJTUF 20758, and SJTUF 20841 were washed with PBS 3 times, harvested by centrifugation at 2,400 $\times g$ for $10 \mathrm{~min}$ at $4^{\circ} \mathrm{C}$, resuspended in PBS $\left(1 \times 10^{6} \mathrm{cfu} /\right.$ $\mathrm{mL}$ ) containing various concentrations of $\mathrm{RJH}$ extract $\left(0, \mathrm{MIC}\right.$, and MBC), and cultured at $37^{\circ} \mathrm{C}$ for $12 \mathrm{~h}$. The samples were collected at $12 \mathrm{~h}$ and filtered through a $0.22-\mu \mathrm{m}$ Millipore filter. The DNA and RNA released from bacterial cells were measured by OD at $260 \mathrm{~nm}$ with Nanodrop (Allsheng). The protein content was determined by bicinchoninic acid protein assay (Takara Bio).

\section{Antibiofilm}

Inhibition of Biofilm Formation. Staphylococcus aureus SJTUF $20758\left(1 \times 10^{6} \mathrm{cfu} / \mathrm{mL}\right)$ was incubated with various concentrations of RJH extract (1/16 MIC, $1 / 8 \mathrm{MIC}, 1 / 4 \mathrm{MIC}, 1 / 2 \mathrm{MIC}$, and $\mathrm{MIC} \mathrm{mg} / \mathrm{mL}$ ) in a 96 -well microtiter plate at $37^{\circ} \mathrm{C}$ for $24 \mathrm{~h}$. Biofilm was quantified by using crystal violet assay as mentioned above.

Eradication of Mature Biofilm. Staphylococcus aureus SJTUF $20758\left(100 \mu \mathrm{L}, 1 \times 10^{6} \mathrm{cfu} / \mathrm{mL}\right)$ was inoculated into each well of a microtiter plate (Corning). Biofilms were established at $37^{\circ} \mathrm{C}$ for $24 \mathrm{~h}$. Preformed biofilms were treated with various concentrations $(1 / 2$ MIC, MIC, $2 \mathrm{MIC}$, and MBC mg/mL) of RJH extract. After treatment at $37^{\circ} \mathrm{C}$ for $24 \mathrm{~h}$, the remaining biofilms were quantified using the crystal violet assay as described above, and the bacterial viability in biofilm was analyzed using the MTT [3-(4,5-dimethylthiazol2-yl)-2,5-diphenyltetrazolium bromide] colorimetric assay (Feng et al., 2018). After removal of supernatant 
in each well, $20 \mu \mathrm{L}$ of MTT $(5 \mathrm{mg} / \mathrm{mL})$ was added and incubated for $4 \mathrm{~h}$ at $37^{\circ} \mathrm{C}$. The purple MTT formazan precipitate was dissolved in $150 \mu \mathrm{L}$ of dimethyl sulfoxide and absorbance determined at $570 \mathrm{~nm}$ using a microplate reader.

Microscopic Visualization of Biofilm. Antibiofilm activity of the RJH extract was evaluated by microscopic visualization of biofilm as described by Bazargani and Rohloff (2016) with a minor modification. For inhibition of biofilm formation, biofilm was established for $24 \mathrm{~h}$ on cover glass slides placed in a 6 -well polystyrene plate with or without RJH extract. For the eradication study, preformed biofilm on cover glass slides was treated with RJH extract for $24 \mathrm{~h}$. After treatment, biofilms were stained with $0.1 \%$ crystal violet and visualized under light microscopy at $100 \times$ magnification.

\section{Motility Inhibition}

For motility inhibition assay, $5 \mu \mathrm{L}$ of overnight culture suspension of Staph. aureus (SJTUF 20772 and 20862) was inoculated onto $0.25 \%$ agar plates containing $1 / 8 \mathrm{MIC}, 1 / 4 \mathrm{MIC}, 1 / 2 \mathrm{MIC}$, and $\mathrm{MIC}(\mathrm{mg} / \mathrm{mL})$ concentrations of RJH extract and incubated at $37^{\circ} \mathrm{C}$ for $24 \mathrm{~h}$. The motility was observed by its movement pattern and distance.

\section{Cytotoxicity}

Cytotoxicity of RJH extract was evaluated in human colon adenocarcinoma cell models, Caco-2 and HT-29, which have typical features of healthy human intestinal epithelial cells (Feng et al., 2018). Caco-2 and HT-29 cells were purchased from the American Type Culture Collection (ATCC) and used within passages 4 to 35 . Cells were cultured in Dulbecco's modified Eagle's medium (Gibco) and supplemented with $10 \%$ fetal bovine serum (Gibco) and 1\% penicillin-streptomycin $(10,000$ $\mathrm{U} / \mathrm{mL}$; Gibco). Cells were maintained in a humidified environment with $5 \% \mathrm{CO}_{2}$ at $37^{\circ} \mathrm{C}$. To evaluate cytotoxic effect, cells were placed $\left(5 \times 10^{3}\right.$ cells/well $)$ in a 96-well microtiter plate for $4 \mathrm{~h}$ at $37^{\circ} \mathrm{C}$ with $5 \% \mathrm{CO}_{2}$ before treatment with various concentrations of $\mathrm{RJH}$ extract $(0.1,0.25,0.5,0.75$, and $1 \mathrm{mg} / \mathrm{mL})$. After treatment for $24 \mathrm{~h}$, cell viability was evaluated using the MTT colorimetric assay as mentioned above.

\section{Time-Kill Assay of RJH Extract Against MDR Staph. aureus in UHT Whole and Skim Milk}

The antibacterial activity of RJH extract in commercial UHT whole and skim milk was determined based on time-kill assay as described by Chang et al. (2017) with modifications. Briefly, $5 \mathrm{~mL}$ of whole or skim milk was inoculated with $1 \times 10^{6} \mathrm{cfu} / \mathrm{mL}$ Staph. aureus SJTUF 20758 at exponential growth phase and incubated at $4^{\circ} \mathrm{C}$ and $25^{\circ} \mathrm{C}$ for $1 \mathrm{~h}$ before $\mathrm{RJH}$ extract treatment (0 MIC, MIC, and MBC) to adapt to each condition. Treated samples were kept for $7 \mathrm{~d}$ at $4^{\circ} \mathrm{C}$ and $25^{\circ} \mathrm{C}$. Viable bacterial cells were enumerated at each day by plating aliquots on Baird-Parker selective agar (Qingdao Haibo Biotechnology Co. Ltd.).

\section{Statistical Analysis}

All experiments were performed in triplicate, and experimental data are presented as mean values \pm standard deviation. Statistical analysis was performed using SPSS 22.0 software (IBM Corp.) and GraphPad Prism 8 (GraphPad Software). The data were analyzed with Student's $t$-test and one-way ANOVA followed by Tukey's multiple comparison test, as appropriate. Significance was considered at $P<0.05$ and $P<0.01$.

\section{RESULTS}

\section{Classification of Staph. aureus Isolates Based on Biofilm Formation and Motility}

Staphylococcus aureus ATCC 25923 and 11 Staph. aureus strains isolated from raw milk were tested for their biofilm-forming abilities using the crystal violet assay. The biofilm-forming ability of strains was categorized by comparing the OD value of each strain with a negative control, as follows: weak $\left(\mathrm{OD}_{\mathrm{NC}}<\mathrm{OD} \leq 2\right.$ $\left.\times \mathrm{OD}_{\mathrm{NC}}\right)$, moderate $\left(2 \times \mathrm{OD}_{\mathrm{NC}}<\mathrm{OD} \leq 4 \times \mathrm{OD}_{\mathrm{NC}}\right)$, or strong $\left(\mathrm{OD}>4 \times \mathrm{OD}_{\mathrm{NC}}\right)$ biofilm producers (Lee et al., 2014). The results showed Staph. aureus strains varied in strong, moderate, and weak biofilm-forming abilities (Table 1). Of the tested Staph. aureus strains, 9 (SJTUF 20758, SJTUF 20978, SJTUF 20745, SJTUF 20841, SJTUF 20862, SJTUF 20772, SJTUF 20755, SJTUF 20746, and SJTUF 20927) were strong biofilm producers. Reference strain (ATCC 25923) formed moderate biofilms, whereas 2 strains (SJTUF 20973 and SJTUF 20991) formed weak biofilms.

Motilities of Staph. aureus strains were evaluated based on movement patterns and distances (Table 1). The motility patterns were divided into 2 groups, spreading or comet gliding. Staphylococcus aureus SJTUF 20746, SJTUF 20755, and SJTUF 20758 showed comet gliding movements, whereas Staph. aureus SJTUF 20772 and SJTUF 20862 exhibited spreading pattern motility on soft agar. The mobile distances of Staph. aureus strains were also measured. Staphylococcus aureus SJTUF 
Table 1. Biofilm formation and motility of Staphylococcus aureus isolated from milk and antibacterial activity of Rumex japonicus

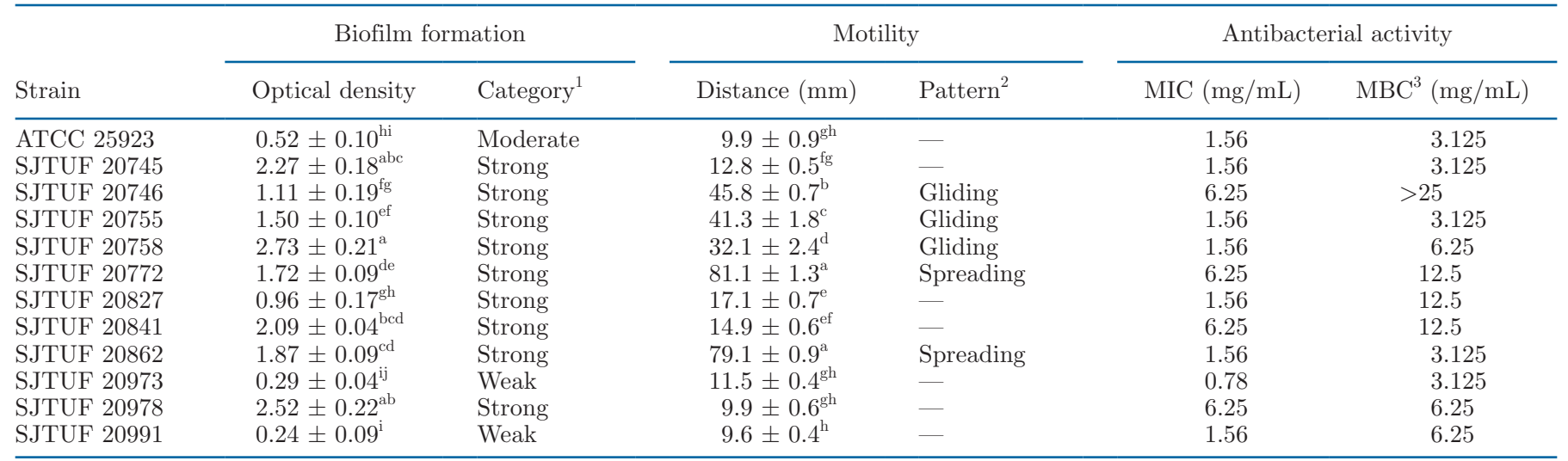

${ }^{\mathrm{a}-\mathrm{j}}$ Different letters within columns indicate significant difference $(P<0.05)$ from one-way ANOVA plus post hoc Tukey test.

${ }^{1}$ Categorized by comparison of each strain's optical density $(\mathrm{OD})$ with the mean $\mathrm{OD}$ value of negative controls $\left(\mathrm{OD}_{\mathrm{NC}}=0.174 \pm 0.01\right)$, according to Lee et al. (2014), as follows: weak $\left(\mathrm{OD}_{\mathrm{NC}}<\mathrm{OD} \leq 2 \times \mathrm{OD}_{\mathrm{NC}}\right)$, moderate $\left(2 \times \mathrm{OD}_{\mathrm{NC}}<\mathrm{OD} \leq 4 \times \mathrm{OD}_{\mathrm{NC}}\right)$, or strong $\left(\mathrm{OD}>4 \times \mathrm{OD}_{\mathrm{NC}}\right)$ biofilm producers.

${ }^{2}$ Categorized by the pattern of movement on $0.25 \%$ swimming agar, according to Pollitt and Diggle (2017).

${ }^{3} \mathrm{MBC}=$ minimum bactericidal concentration.

20772 and SJTUF 20862 moved the farthest, followed by SJTUF 20746, SJTUF 20755, and SJTUF 20758. Other strains showed weak motility.

\section{Phytochemical Compounds in RJH Extract}

The phytochemical compounds in RJH extract were identified using HPLC-LTQ/Orbitrap-MS analysis (Table 2). The RJH extract contained anthraquinones (emodin, chrysophanol, physcion, and emodin-8-glucoside), flavonoids (4',5,6,7-tetramethoxyflavone and methyl ether isotectorigenin), terpenoids (myrianthic acid), and naphthalenes (trachrysone and nepodin).

\section{Antibacterial Activity of the RJH Extract}

The MIC and MBC of RJH extract were determined against 1 reference and 11 MDR Staph. aureus strains (Table 1). The results showed that the RJH extract had antibacterial activities against all 12 Staph. aureus strains. The MIC values ranged from 0.78 to $6.25 \mathrm{mg} /$ $\mathrm{mL}$. Except for SJTUF 20746 (MBC $>25 \mathrm{mg} / \mathrm{mL}$ ), the

Table 2. Compounds identified in Rumex japonicus Houtt. extract using HPLC-linear trap quadrupole/orbitrap-MS

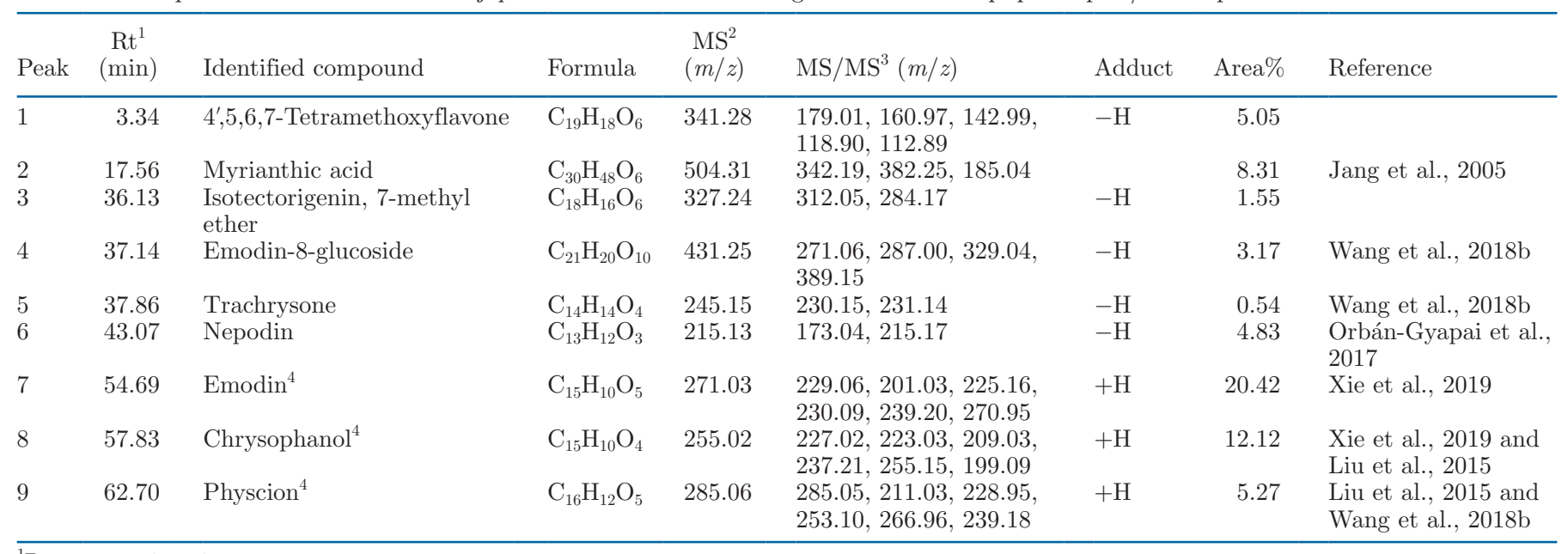

\footnotetext{
${ }^{1} \mathrm{Rt}=$ retention time.
}

${ }^{2}$ Precursor ion.

${ }^{3}$ Product ions, after fragmentation of precursor ion.

${ }^{4}$ Confirmed with a standard compound. 
MBC values for Staph. aureus strains ranged from 3.125 to $12.5 \mathrm{mg} / \mathrm{mL}$. In the time-kill analysis (Figure 1), RJH extract showed good antibacterial activity against Staph. aureus strains in a concentration-dependent manner. At the MBC, the viable cells of Staph. aureus SJTUF 20841 decreased by $99.9 \%$ within $12 \mathrm{~h}$. For all other Staph. aureus strains, the number of viable cells was reduced within $24 \mathrm{~h}$. The extract at the MIC concentration exhibited bacteriostatic activities against Staph. aureus.

\section{Cell Membrane Integrity}

The leakage of cell constituents was measured to study the effect of RJH extract on the integrity of Staph. aureus cell membrane. As shown in Figure 2, compared with untreated cells, Staph. aureus ATCC 25923, SJTUF 20745, SJTUF 20758, and SJTUF 20841 treated with MBC concentrations of RJH extract had significantly more leakage of nucleic acids and proteins from cells $(P<0.01)$. However, the Staph. aureus
A

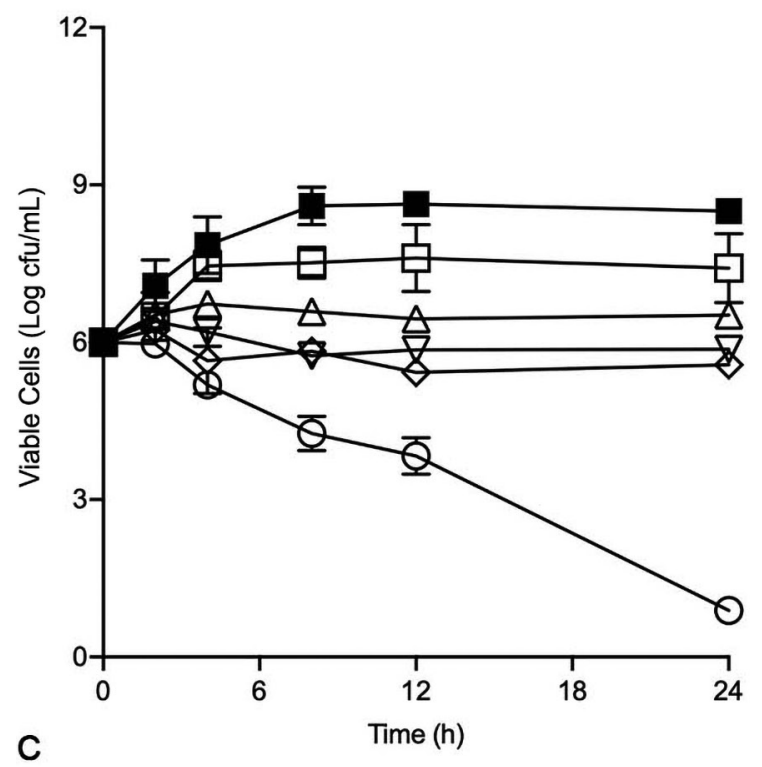

C

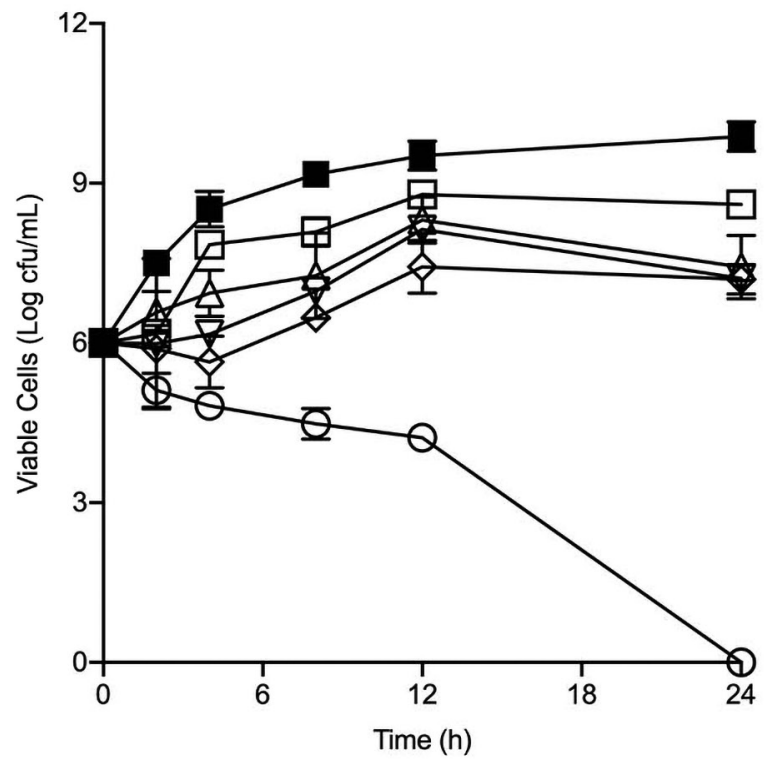

B
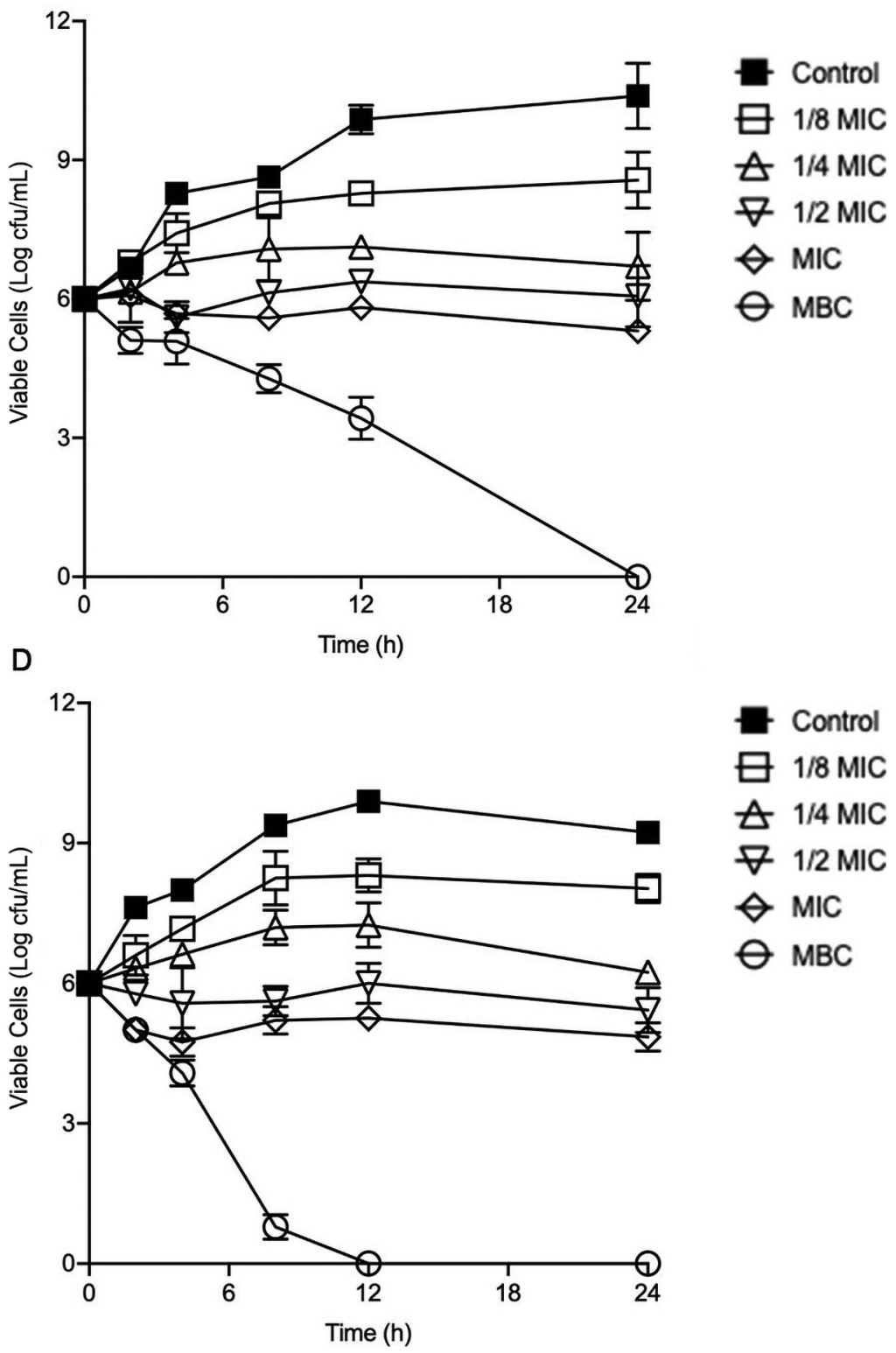

Figure 1. Time-kill assay of Rumex japonicus Houtt. extract at 1/8 MIC, 1/4 MIC, 1/2 MIC, MIC, and minimum bacterial concentration (MBC) values against one reference (A) and 3 MDR Staphylococcus aureus strains, SJTUF 20745 (B), SJTUF 20758 (C) and SJTUF 20841 (D). Error bars represent standard deviations. 


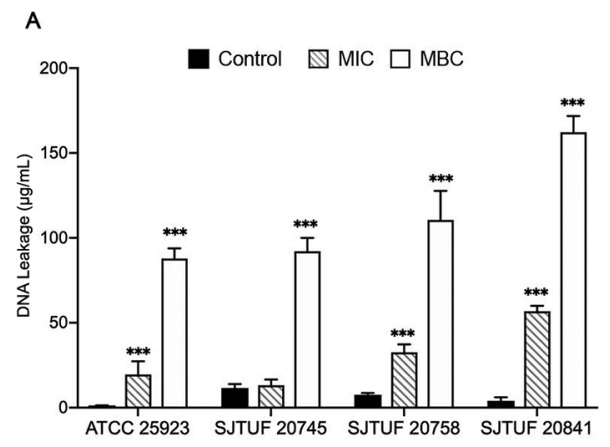

B

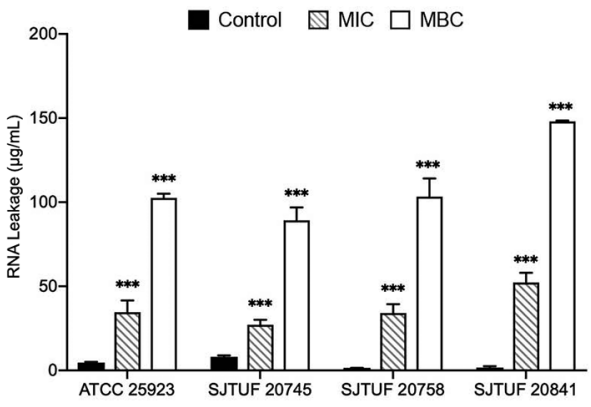

C

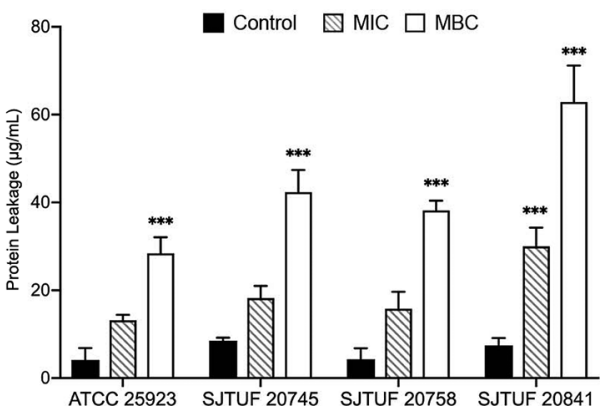

Figure 2. Leakage of DNA (A), RNA (B) and protein (C) from one reference and 3 multidrug-resistant Staphylococcus aureus strains treated with Rumex japonicus Houtt. extract at 0 , MIC, and minimum bacterial concentration (MBC) for $12 \mathrm{~h}$. ${ }^{* * *} P<0.01$ compared with control group. Error bars represent standard deviations.

strains treated at MIC concentration exhibited less leakage, compared with MBC concentration, after 12 $\mathrm{h}$ of treatment.

\section{Antibiofilm Effects of RJH Extract}

To evaluate the antibiofilm effects of RJH extract, Staph. aureus SJTUF 20758 was used because it was shown to have the strongest biofilm production. As shown in Figure 3A, sublethal concentrations of RJH extract inhibited biofilm formation of Staph. aureus in a concentration-dependent manner. The RJH extract treatments at $1 / 2$ MIC and MIC showed reduction (81.9\% and $86.7 \%$, respectively) in biofilm formation. The RJH extract at 1/4 MIC exhibited $38.7 \%$ inhibition of biofilm formation. Light microscopy analysis demonstrated that Staph. aureus treated with RJH extract at 1/2 MIC concentration showed poor biofilm development compared with the untreated control (Figure $4 \mathrm{~A}$ and $\mathrm{B}$ ).

Mature biofilm of Staph. aureus was used to investigate the biofilm-disruption levels by RJH extract. Mature biofilm was treated with various concentrations of RJH extract (MIC, $2 \mathrm{MIC}$, and MBC) for $24 \mathrm{~h}$, and biofilm was quantified using the crystal violet assay. As shown in Figure 3B, RJH extract was effective to eradicate biofilm in a concentration-dependent manner. The percentages of biomass reduction by $\mathrm{RJH}$ extract exposure were $27.4 \%, 66.5 \%$, and $78.6 \%$ at MIC, 2 $\mathrm{MIC}$, and MBC values, respectively. Light microscopy images showed that the mature biofilm was destroyed by RJH extract at 2 MIC compared with untreated control (Figure 4C and D). In addition, the MTT assay was used to measure metabolically active cells in biofilm after RJH exposure (Figure 3C). After $24 \mathrm{~h}$ of treatment with various concentrations $(1 / 2 \mathrm{MIC}, \mathrm{MIC}$, $2 \mathrm{MIC}$, and $\mathrm{MBC}$ ) of the RJH extract, the reductions in metabolic activity of viable cells in mature biofilm were $25.2 \%, 15.2 \%, 4.0 \%$, and $3.2 \%$, respectively.

\section{Antimotility}

Because of their different motility patterns, Staph. aureus SJTUF 20758 and SJTUF 20772 strains were used to evaluate the antimotility effects of RJH extract. The RJH extract inhibited the spreading and comet gliding migration of Staph. aureus in a concentrationdependent manner (Figure 5). For Staph. aureus SJTUF 20758, which has comet gliding movement, the extract exhibited a strong effect in blocking its movement at 1/4 MIC, 1/2 MIC, and MIC (Figure 5A). However, the extract had good spreading inhibition of Staph. aureus SJTUF 20772 only at the MIC (Figure 5B).

\section{Cytotoxicity of RJH Extract}

The cytotoxic effect of RJH extract in Caco-2 and HT-29 cells was evaluated by MTT assay after $24 \mathrm{~h}$ of exposure (Figure 6). The results indicated that RJH extract did not affect the multiplication capacity of Caco-2 or HT-29 cells at concentrations ranging from 0.1 to $0.5 \mathrm{mg} / \mathrm{mL}$ and from 0.1 to $0.75 \mathrm{mg} / \mathrm{mL}$, respectively.

\section{Application of RJH Extract in UHT Whole Milk and Skim Milk}

To investigate the antibacterial activity of $\mathrm{RJH}$ extract against Staph. aureus SJTUF 20758 in a food matrix, UHT whole milk and skim milk were used as food models. Staphylococcus aureus was treated with the MIC and MBC values of RJH extract and incubated at $4^{\circ} \mathrm{C}$ or $25^{\circ} \mathrm{C}$ for $7 \mathrm{~d}$. As shown in Figure 7 , in whole and skim milk treated with MBC and stored 
A

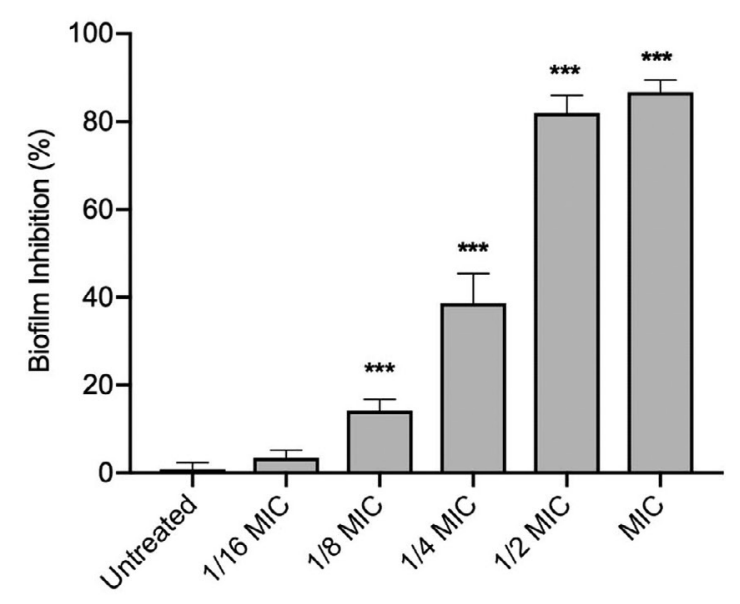

B

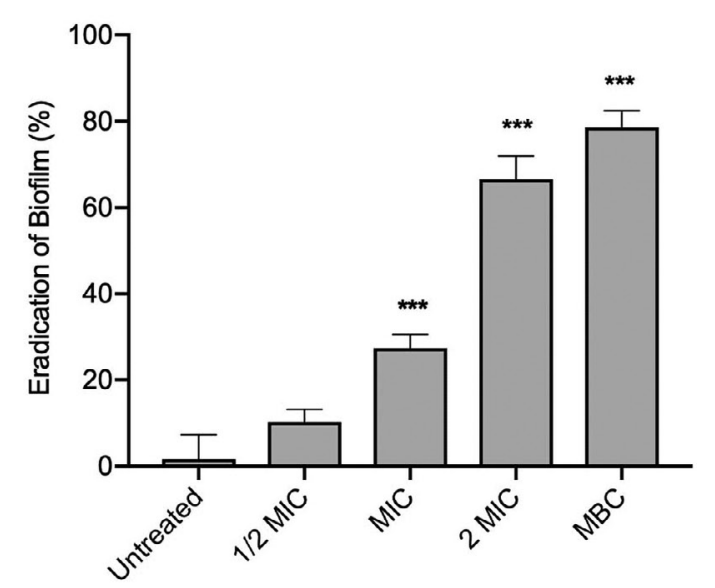

C

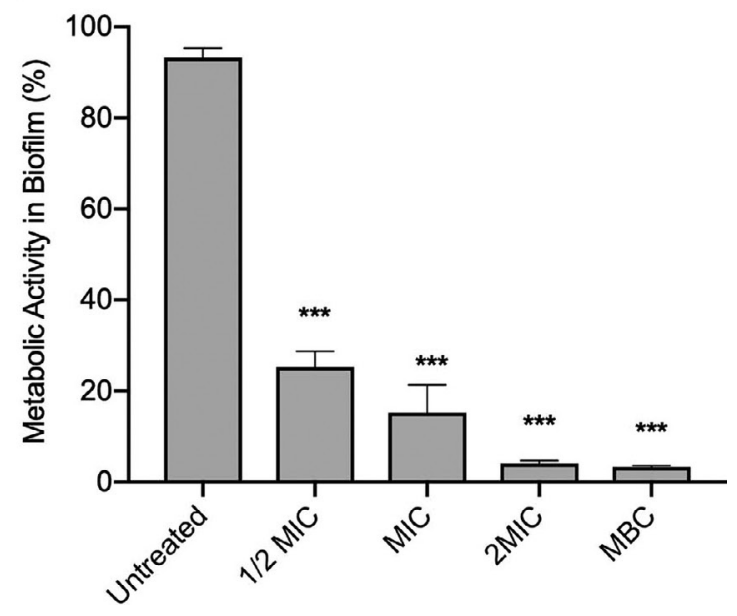

Figure 3. Antibiofilm effect of Rumex japonicus Houtt. (RJH) extract on Staphylococcus aureus SJTUF 20758. Inhibition of biofilm formation by sublethal concentration of RJH extract (A), eradication of biofilm by RJH extract (B), and effect of RJH extract on metabolic activity of bacterial cells within biofilm $(\mathrm{C})$. MBC $=$ minimum bacterial concentration. ${ }^{* * *} P<0.01$ compared with untreated (control) group. Error bars represent standard deviations. at $4^{\circ} \mathrm{C}$, Staph. aureus viable cells decreased by 4.8 and $4.2 \log _{10} \mathrm{cfu} / \mathrm{mL}$, respectively. In the case of storage at $25^{\circ} \mathrm{C}$, the reduction in cell viability was not observed in whole milk, whereas bacterial growth was inhibited (from 5.8 to $4.7 \log _{10} \mathrm{cfu} / \mathrm{mL}$ ) in skim milk after $3 \mathrm{~d}$ of administration in a time-dependent manner. The antibacterial activity of RJH extract was relatively effective in skim milk compared with whole milk.

\section{DISCUSSION}

The prevalence of MDR Staph. aureus with strong virulence has become a major concern due to the increasing cases of failure of antimicrobials in the milk and dairy industries, leading to economic loss and food safety issues (Founou et al., 2016). In our previous study, we reported that Staph. aureus isolated from milk has shown resistance to antibiotics including erythromycin, ciprofloxacin, clindamycin, gentamicin, penicillin, and streptomycin, and most isolates have MDR (Zhang et al., 2019). Forming bacterial biofilms is one of the survival strategies of Staph. aureus to tolerate antimicrobial agents and other external stress by interfering with the penetration of antimicrobials into biofilm (Rabin et al., 2015). Many studies have reported the correlation of MDR and biofilm formation of Staph. spp. isolated from milk and dairy industries (Wang et al., 2018a; Meroni et al., 2019; Bissong and Ateba, 2020). In this study, a similar finding was observed that 9 MDR isolates had strong biofilm formation ability among 11 isolates (Table 1). Motility, one of the virulence factors, is also important for biofilm formation because motility is involved in the initial adhesion on abiotic and biotic surfaces (Bai et al., 2019). Although Staph. aureus is not flagellated, spreading or comet gliding motility has been observed (Pollitt and Diggle, 2017). Among the isolates, bacterial strains with spreading motility moved farther compared with strains with gliding motility (Table 1).

The elimination of MDR Staph. aureus and its biofilms in milk and dairy products have remained a major concern (Aslantaş and Demir, 2016; Unlu et al., 2018). In attempts to discover new antimicrobials, plant extracts have been studied because of their significant antibacterial properties, safety, and accessibility (Silva et al., 2016; Ma et al., 2018). In addition, plant extracts contain various phytochemical compounds with structural diversity, which can efficiently combat MDR bacteria by targeting multiple sites (Silva et al., 2016). The plant RJH belongs to the Polygonaceae family, which has several nutraceutical effects such as antioxidant, antimicrobial, anti-inflammatory, anticancer, and antidiabetic activities (Sun et al., 2020). Nishina et al. (1993) reported that an $n$-hexane extract of RJH root 
had broad-spectrum antibacterial activity against foodborne pathogens including Staph. aureus. Elzaawely et al. (2005) demonstrated that the ethyl acetate extract of aerial parts of $\mathrm{RJH}$ had strong antibacterial activity against Bacillus subtilis, Bacillus cereus, and Escherichia coli. In the current study, ethanol was used as an extraction solvent due to its safety and good extraction efficiency to obtain antibacterial compounds. We identified the phytochemical constituents of RJH by HPLC-MS, which are $4^{\prime}, 5,6,7$-tetramethoxyflavone, myrianthic acid, 7-methyl ether isotectorigenin, emodin-8-glucoside, trachrysone, nepodin, emodin, chrysophanol, and physcion (Table 2). Nishina et al. (1993) demonstrated the antibacterial activity of trachrysone in RJH against Staph. aureus, B. subtilis, E. coli, and Salmonella typhimurium (MIC values ranged from 100 to $200 \mathrm{mg} / \mathrm{L}$ ). In addition, many studies have been investigated on the antibacterial activities of emodin, chrysophanol, and physcion (Basu et al., 2005; Wang et al., 2010; Sun et al., 2019; XunLi et al., 2019). Basu et al. (2005) reported that emodin and physcion isolated from Ventilago madraspatana exhibited broad-spectrum antibacterial activities against gram-positive (B. cereus, B. pumilus, and B. subtilis) and gram-negative bacteria (Pseudomonas aeruginosa and Klebsiella pneumoniae) with MIC values ranging from 0.5 to $2.0 \mu \mathrm{g} / \mathrm{mL}$ and from 70.0 to $250.0 \mu \mathrm{g} / \mathrm{mL}$, respectively. Nakano et al. (2012) identified chrysophanol, physcion, nepodin, and emodin in Atraphaxis laetevirens that showed antibacterial activity against Flavobacterium columnare and Streptococcus iniae. Consistent with the previous studies, the strong antibacterial activity of RJH extract could be attributed to the inclusion of antibacterial compounds, trachrysone, nepodin, emodin, chrysophanol, and physcion.

The antibacterial activity of RJH extract has been studied (Nishina et al., 1993; Elzaawely et al., 2005), but its bactericidal activity against MDR bacteria, its mechanism of antibacterial action, and antivirulence effects had remained uninvestigated. In the present study, the hydroethanolic RJH extract showed good bactericidal effects on MDR Staph. aureus isolates, having different antibiotic-resistant patterns (Table 1). The extract presented bactericidal effects on 4 MDR
A

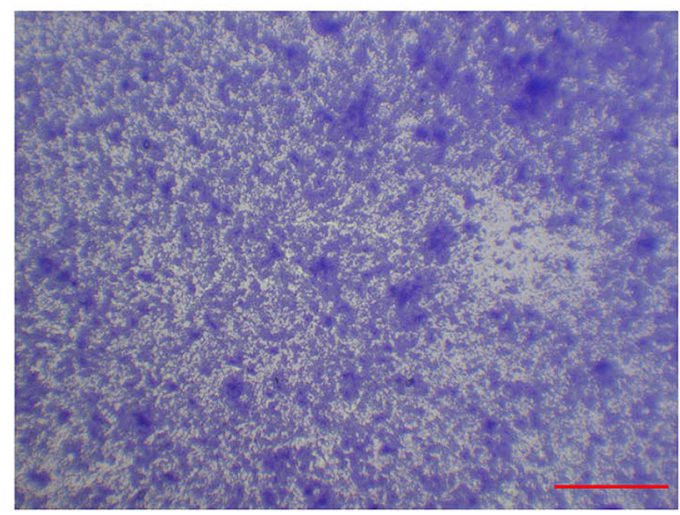

C

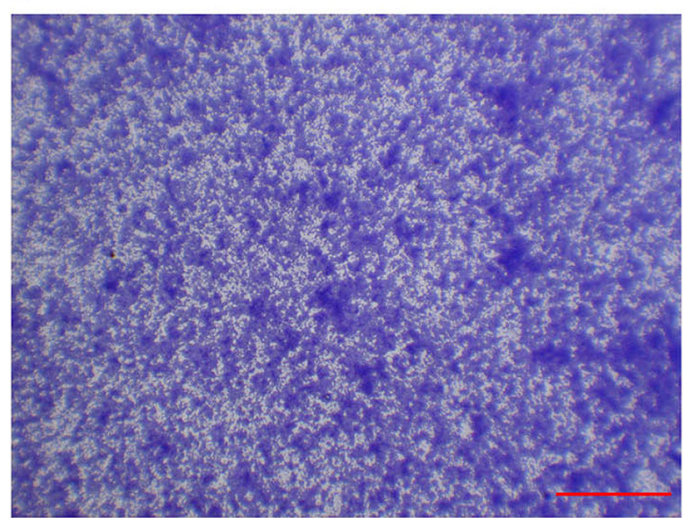

B
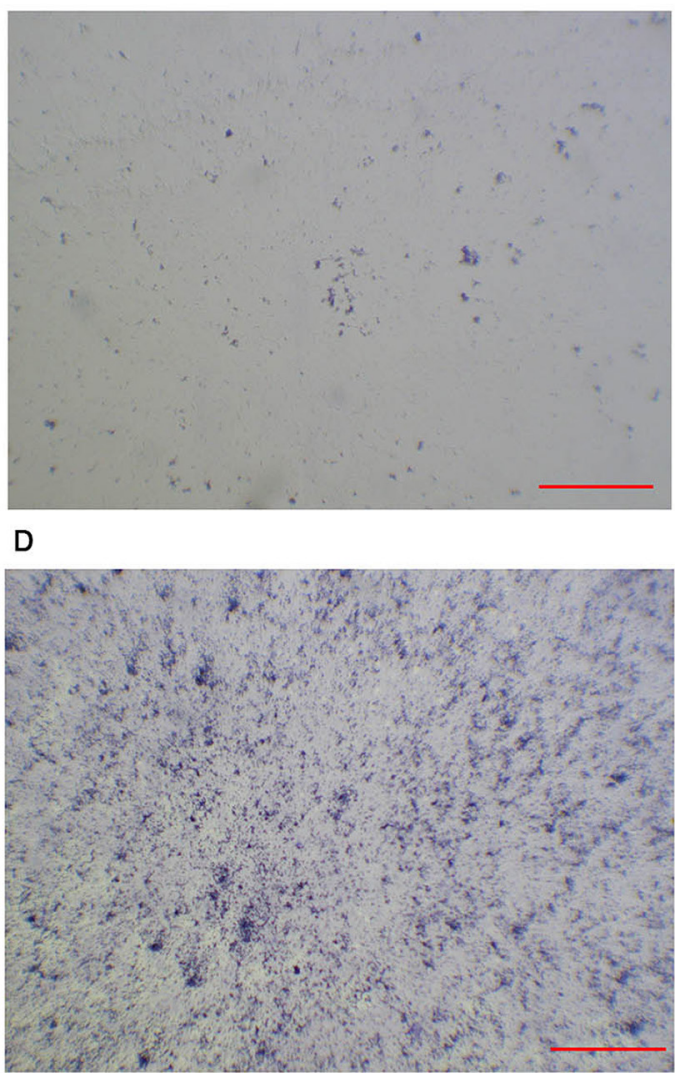

Figure 4. Light micrographs $(100 \times$ magnification; scale bars $=100 \mu \mathrm{m})$ of Staphylococcus aureus SJTUF 20758 biofilms. Inhibition of biofilm formation: control (A) and treatment of Rumex japonicus Houtt. (RJH) extract at 1/2 MIC (B). Eradication of established biofilms: control (C) and treatment of RJH extract at minimum bacterial concentration (D). 
A

Control

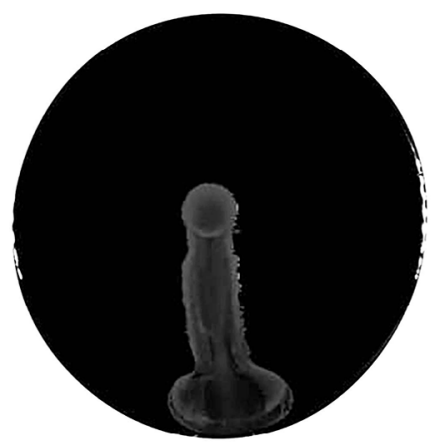

B

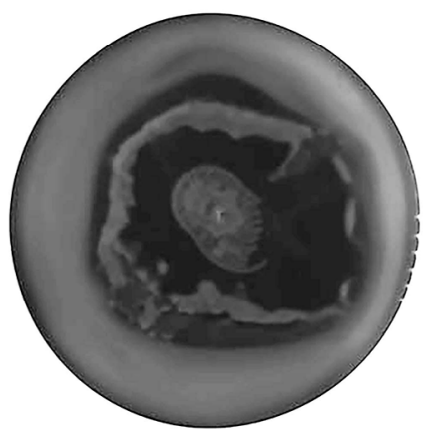

$1 / 8 \mathrm{MIC}$
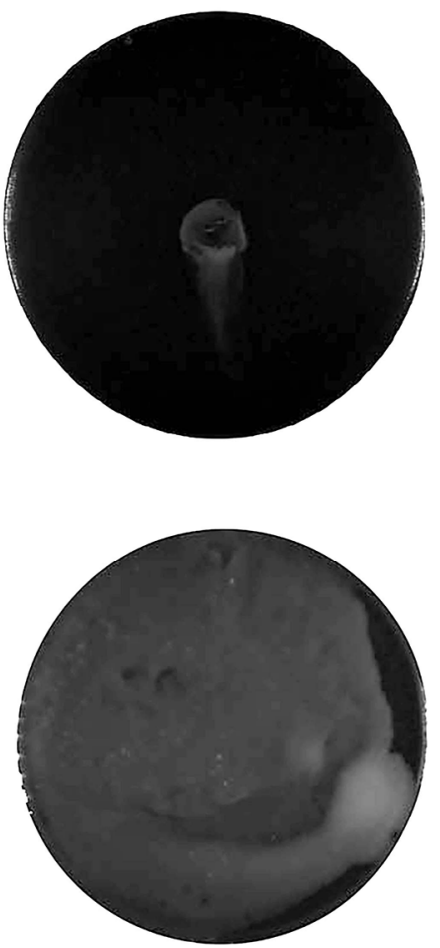

$1 / 4 \mathrm{MIC}$
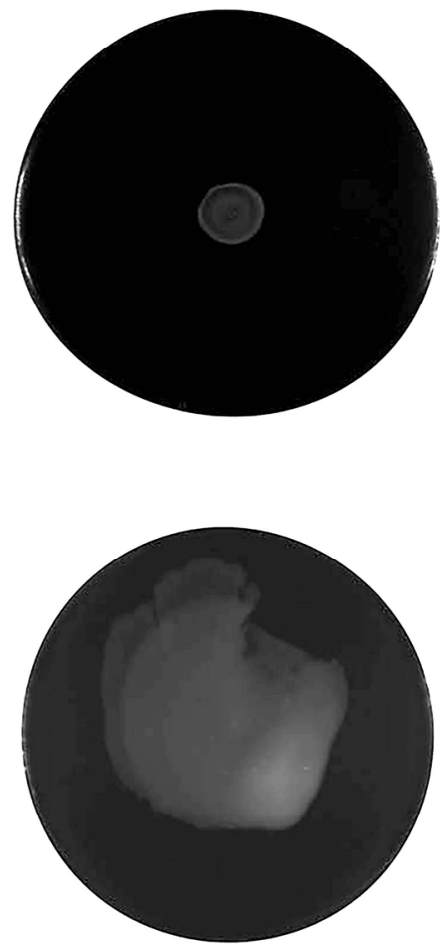

$1 / 2$ MIC
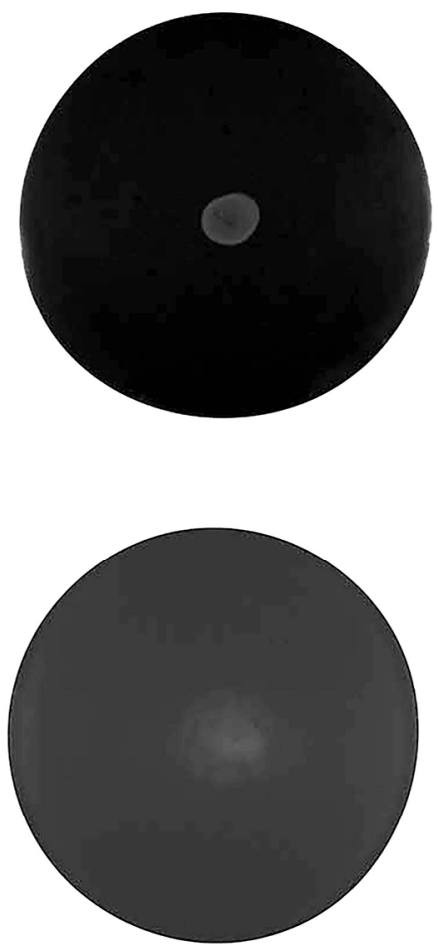

Figure 5. Antimotility of Staphylococcus aureus SJTUF 20772 (A: gliding movement) and SJTUF 20862 (B: spreading movement) treated with $0,1 / 8 \mathrm{MIC}, 1 / 4 \mathrm{MIC}$, and 1/2 MIC.

A

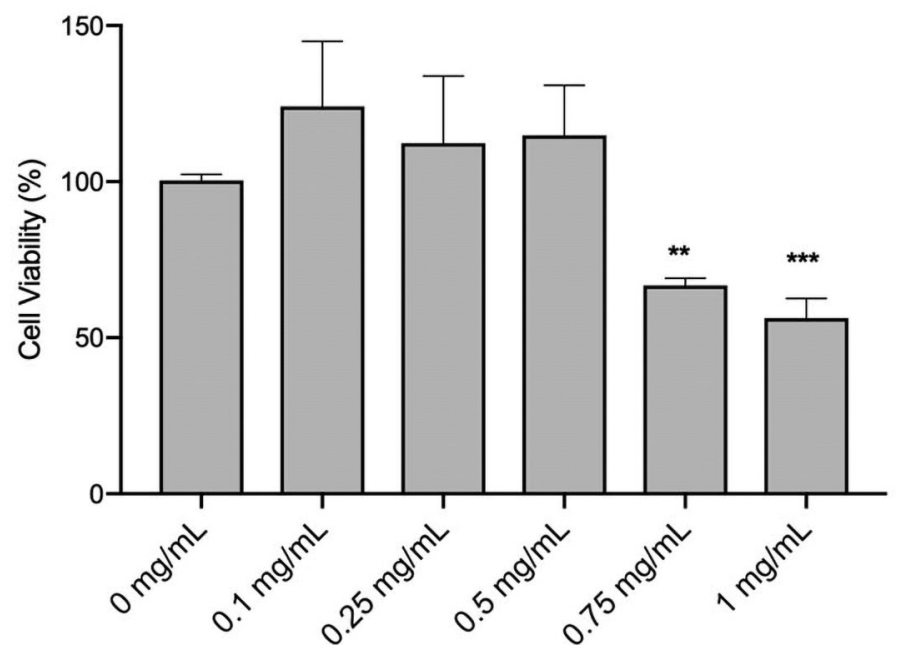

B

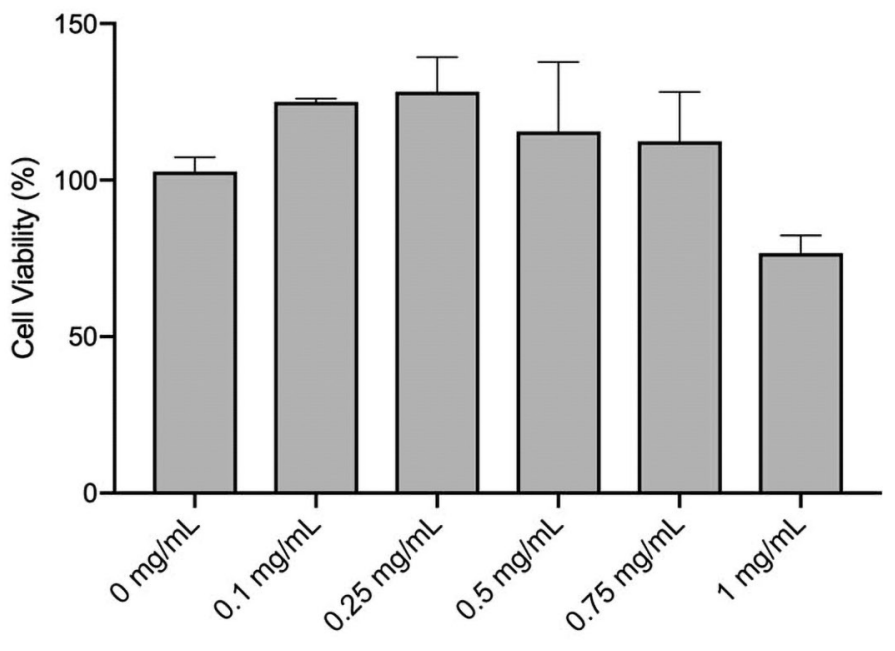

Figure 6. The viability of Caco-2 (A) and HT-29 (B) cells exposed to various concentrations $(0.1,0.25,0.5,0.75$, and $1 \mathrm{mg} / \mathrm{mL})$ of $R$ umex japonicus Houtt. extract for $24 \mathrm{~h}$ assessed by the colorimetric assay using MTT. ${ }^{* *} P<0.05$ and ${ }^{* * *} P<0.01$ compared with untreated group. Error bars represent standard deviations. 
Staph. aureus within $12 \mathrm{~h}$ at MBC, as well as bacteriostatic effects at MIC levels (Figure 1). Many studies have reported the mechanism of antibacterial action of plant extracts; for example, changing cell morphology, disrupting cell wall, and altering membrane permeability eventually lead to cell death (Bai et al., 2015; Kang and Song, 2019; Zheng et al., 2019; Zhu et al., 2020). In agreement with previous studies, we observed that the $\mathrm{RJH}$ extract at MBC triggered the leakage of intracellular contents such as nucleic acids and proteins in 4
MDR Staph. aureus, indicating that RJH extract disintegrated bacterial cytoplasmic membrane, increased its permeability, and thereby caused cell death (Figure 2 ). Aside from the bactericidal activity with multiple targets, restraining bacterial virulent factors is a good strategy to combat MDR bacteria and to inhibit the development of MDR bacteria in the food industry (Silva et al., 2016). In this study, we evaluated antivirulence effects of RJH extract, including antibiofilm and antimotility activities, against MDR isolates from milk.
A

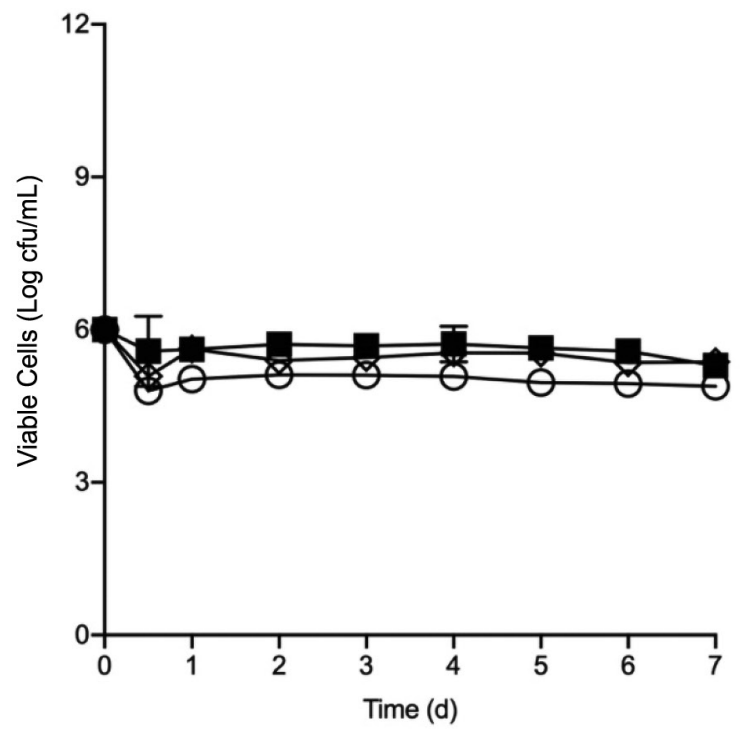

C

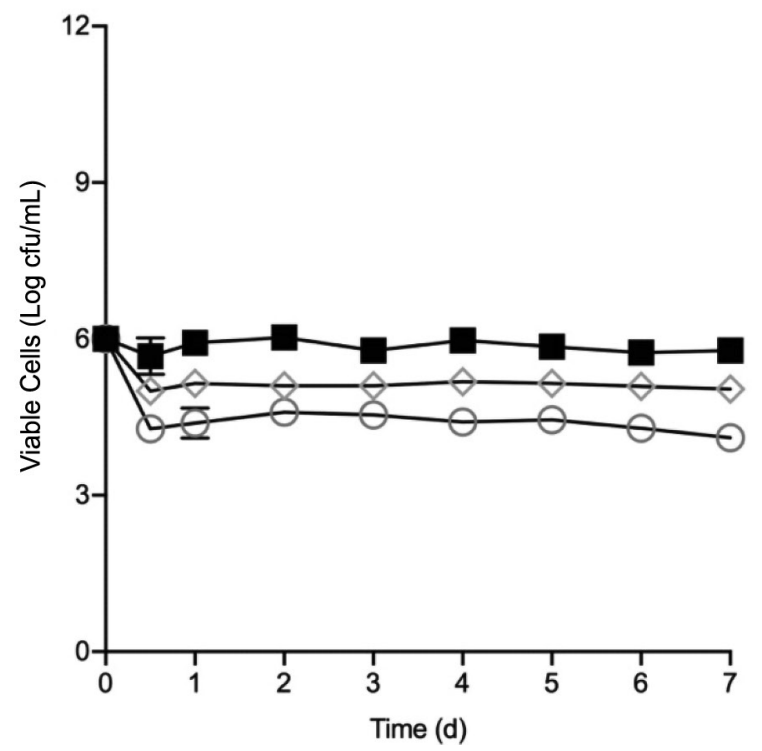

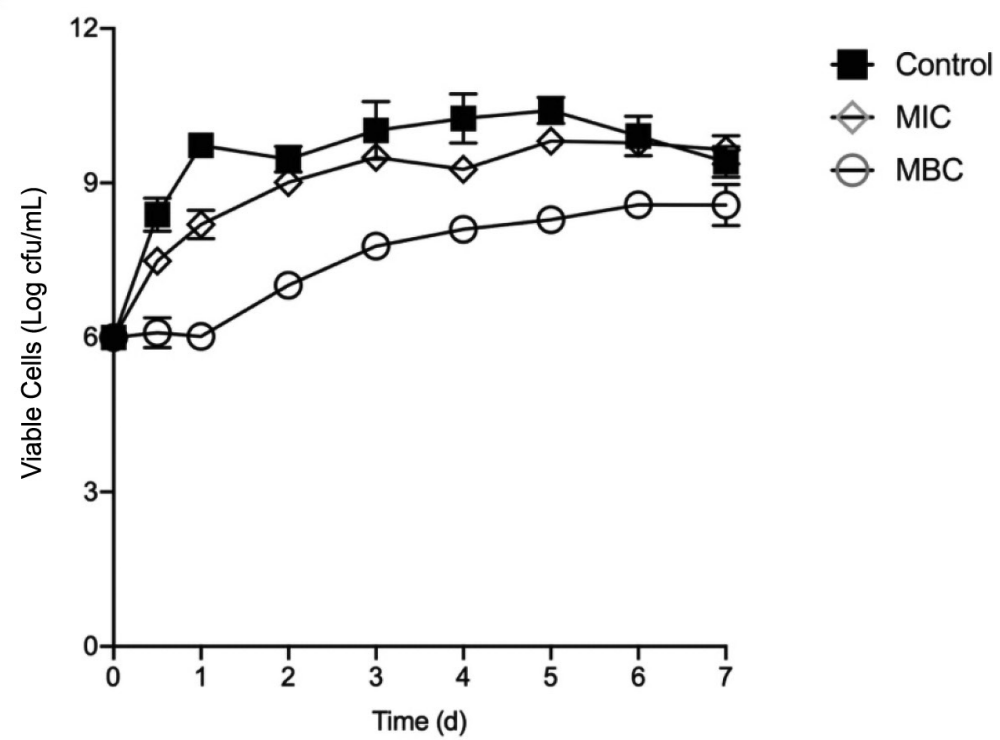

D

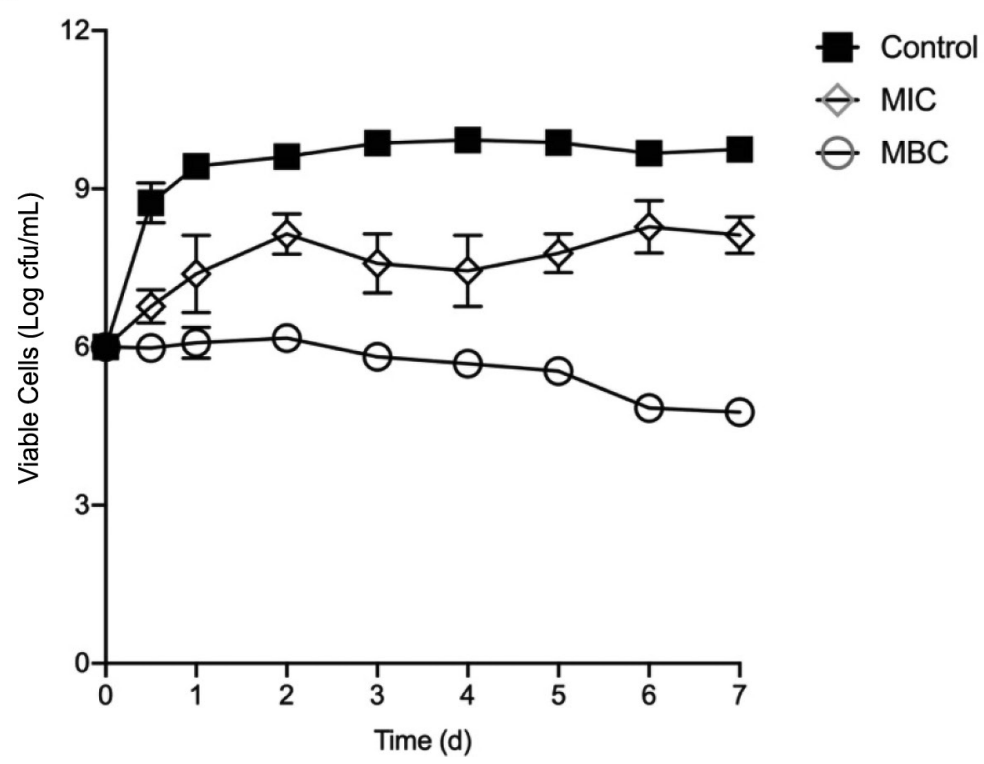

Figure 7. Antibacterial activity of Rumex japonicus Houtt. (RJH) extract at 0, MIC, and minimum bacterial concentration (MBC) in whole milk (A, B) and skim milk (C, D). Effect of RJH extract on growth of Staphylococcus aureus SJTUF 20758 in milk incubated at $4^{\circ} \mathrm{C}(\mathrm{A}, \mathrm{C})$ and $25^{\circ} \mathrm{C}(\mathrm{B}, \mathrm{D})$ for $7 \mathrm{~d}$. 
At sub-MIC concentration $(0.78 \mathrm{mg} / \mathrm{mL})$, the biofilm formation was inhibited approximately $81.8 \%$ without affecting the growth of planktonic cells (Figure 1 and Figure 3A). This indicated that the biofilm formation inhibitory effect is more likely to involve inhibiting the initial attachment of bacteria and reducing biomass production, and not due to death of cells by the RJH extract. The antimotility activity of RJH extract could result in inhibition of staphylococcal adhesion capacity, thereby disturbing the surface colonization and biofilm formation (Figure 5). Biofilms are composed of extracellular polymeric substances secreted by adhesion cells and act as a natural barrier by blocking the penetration of antimicrobials owing to the integrity of biofilm architecture (Lister and Horswill, 2014). Additionally, biofilm-associated bacteria are metabolically inactive and at dormant state, leading to more resistance to the antimicrobial agents compared with planktonic bacteria (Harrison et al., 2005). Interestingly, we found that the treatment of mature biofilm with RJH extract (2 MIC and MBC) reduced biofilm biomass and viable cells in biofilms (Figure 3B and C).

We next evaluated the antibacterial activity of RJH against MDR Staph. aureus in food matrix using UHT whole milk and skim milk as the example models. The extract exhibited a reduction of Staph. aureus viable cells in skim milk more than in whole milk (Figure 7), supporting previous studies that also found a weak antibacterial activity in whole milk (Cava et al., 2007; Higginbotham et al., 2014; Chang et al., 2017). Less efficacy of RJH extract in whole milk might be attributed to interference with milk fat globules, proteins, and carbohydrates, providing the protection of bacteria (Higginbotham et al., 2014). In general, RJH extract at MBC concentration showed the bacteriostatic effect of MDR strain in skim milk for long-term storage.

Last, we evaluated the cytotoxic effects of RJH extract on human epithelial cell lines such as Caco-2 and HT-29 cells (Figure 6). The RJH extract showed nontoxic effects on Caco-2 cell line and HT-29 cell line, demonstrating that RJH extract may be safe to human within a certain concentration.

This study showed that MDR Staph. aureus isolated from milk exhibited strong virulent properties. Our results demonstrated that $\mathrm{RJH}$ extract exhibited bactericidal activity against MDR bacteria by disrupting the integrity of the cell membrane and could be directly applicable in the food matrix. The strong antivirulence effects of RJH extract, such as antibiofilm and antimotility, were also observed, suggesting a potential antibiofilm agent. To overcome MDR pathogens and to meet consumers demand for food free from artificial agents, the RJH extract could be an alternative to synthetic preservatives in the food industry. In spite of nontoxic effects on epithelial cell lines in the present study, further studies are necessary to evaluate the toxicity of RJH extract in vivo for safety assurance in milk and dairy industries. Furthermore, physicochemical and sensory properties of milk containing RJH extract need to be evaluated their application in milk and dairy products.

\section{ACKNOWLEDGMENTS}

This work was supported by the National Key R\&D Program of China (Beijing; 2017YFC1600100). The authors have not stated any conflicts of interest.

\section{REFERENCES}

Ackerman, D. L., K. M. Craft, R. S. Doster, J. H. Weitkamp, D. M. Aronoff, J. A. Gaddy, and S. D. Townsend. 2018. Antimicrobial and antibiofilm activity of human milk oligosaccharides against Streptococcus agalactiae, Staphylococcus aureus, and Acinetobacter baumannii. ACS Infect. Dis. 4:315-324. https://doi.org/10.1021/ acsinfecdis.7b00183.

Alfaifi, M. Y., J. Alkabli, and R. F. M. Elshaarawy. 2020. Suppressing of milk-borne pathogenic using new water-soluble chitosan-azidopropanoic acid conjugate: Targeting milk-preservation quality improvement. Int. J. Biol. Macromol. 164:1519-1526. https://doi .org/10.1016/j.ijbiomac.2020.07.200.

Aminov, R. I. 2009. The role of antibiotics and antibiotic resistance in nature. Environ. Microbiol. 11:2970-2988. https://doi.org/10 .1111/j.1462-2920.2009.01972.x.

Aslantaş, Ö., and C. Demir. 2016. Investigation of the antibiotic resistance and biofilm-forming ability of Staphylococcus aureus from subclinical bovine mastitis cases. J. Dairy Sci. 99:8607-8613. https: //doi.org/10.3168/jds.2016-11310.

Babić, M., M. Pajić, M. Radinović, S. Boboš, S. Bulajić, A. Nikolić and B. Velebit. 2019. Effects of temperature abuse on the growth and staphylococcal enterotoxin A gene (sea) expression of Staphylococcus aureus in milk. Foodborne Pathog. Dis. 16:282-289. https: //doi.org/10.1089/fpd.2018.2544.

Bai, J., Y. Wu, X. Liu, K. Zhong, Y. Huang, and H. Gao. 2015. Antibacterial activity of shikimic acid from pine needles of Cedrus deodara against Staphylococcus aureus through damage to cell membrane. Int. J. Mol. Sci. 16:27145-27155. https://doi.org/10 $.3390 /$ ijms161126015.

Bai, J. R., K. Zhong, Y. P. Wu, G. Elena, and H. Gao. 2019. Antibiofilm activity of shikimic acid against Staphylococcus aureus. Food Control 95:327-333. https://doi.org/10.1016/j.foodcont.2018 .08 .020 .

Basu, S., A. Ghosh, and B. Hazra. 2005. Evaluation of the antibacterial activity of Ventilago madraspatana Gaerten., Rubia cordifolia Linn. and Lantana camara Linn.: Isolation of emodin and physcion as active antibacterial agents. Phytother. Res. 19:888-894. https:/ /doi.org/10.1002/ptr.1752.

Bazargani, M. M., and J. Rohloff. 2016. Antibiofilm activity of essential oils and plant extracts against Staphylococcus aureus and Escherichia coli biofilms. Food Control 61:156-164. https://doi.org/10 .1016/j.foodcont.2015.09.036.

Bissong, M. E. A., and C. N. Ateba. 2020. Genotypic and phenotypic evaluation of biofilm production and antimicrobial resistance in Staphylococcus aureus isolated from milk, north west province, South Africa. Antibiotics (Basel) 9:156. https://doi.org/10.3390/ antibiotics 9040156 .

Cava, R., E. Nowak, A. Taboada, and F. Marin-Iniesta. 2007. Antimicrobial activity of clove and cinnamon essential oils against Listeria monocytogenes in pasteurized milk. J. Food Prot. 70:27572763. https://doi.org/10.4315/0362-028X-70.12.2757. 
Chang, Y., H. Yoon, D. H. Kang, P. S. Chang, and S. Ryu. 2017. Endolysin LysSA97 is synergistic with carvacrol in controlling Staphylococcus aureus in foods. Int. J. Food Microbiol. 244:19-26. https://doi.org/10.1016/j.ijfoodmicro.2016.12.007.

Chen, J., S. Kawamura, and S. Koseki. 2020a. Effect of D-tryptophan on the psychrotrophic growth of Listeria monocytogenes and its application in milk. Food Control 110:107048. https://doi.org/10 $.1016 / j$.foodcont.2019.107048.

Chen, J., C. Tang, R. Zhang, S. Ye, Z. Zhao, Y. Huang, X. Xu, W. Lan, and D. Yang. 2020b. Metabolomics analysis to evaluate the antibacterial activity of essential oil from the leaves of Cinnamomum camphora (Linn.). J. Ethnopharmacol. 253:112652. https:// doi.org/10.1016/j.jep.2020.112652.

Elzaawely, A. A., T. D. Xuan, and S. Tawata. 2005. Antioxidant and antibacterial activities of Rumex japonicus Houtt. aerial parts. Biol. Pharm. Bull. 28:2225-2230. https://doi.org/10.1248/bpb.28 .2225 .

Felipe, V., M. L. Breser, L. P. Bohl, E. R. da Silva, C. A. Morgante, S. G. Correa, and C. Porporatto. 2019. Chitosan disrupts biofilm formation and promotes biofilm eradication in Staphylococcus species isolated form bovine mastitis. Int. J. Biol. Macromol. 126:60-67. https://doi.org/10.1016/j.ijbiomac.2018.12.159.

Feng, Y., N. Li, H. Ma, B. Bei, Y. Han, and G. Chen. 2018. Undescribed phenylethyl flavones isolated from Patrinia villosa show cytoprotective properties via the modulation of the mir-144-3p/Nrf2 pathway. Phytochemistry 153:28-35. https://doi.org/10.1016/j .phytochem.2018.05.016.

Founou, L. L., R. C. Founou, and S. Y. Essack. 2016. Antibiotic resistance in the food chain: A developing country-perspective. Front. Microbiol. 7:1881. https://doi.org/10.3389/fmicb.2016.01881.

Frank, J. F., and R. A. Koffi. 1990. Surface-adherent growth of Listeria monocytogenes is associated with increased resistance to surfactant sanitizers and heat. J. Food Prot. 53:550-554. https://doi .org/10.4315/0362-028X-53.7.550.

Gatadi, S., Y. V. Madhavi, S. Chopra, and S. Nanduri. 2019. Promising antibacterial agents against multidrug resistant Staphylococcus aureus. Bioorg. Chem. 92:103252. https://doi.org/10.1016/j .bioorg.2019.103252.

Gyawali, R., and S. A. Ibrahim. 2014. Natural products as antimicrobial agent. Food Control 46:412-429. https://doi.org/10.1016/ j.foodcont.2014.05.047.

Harrison, J. J., R. J. Turner, and H. Ceri. 2005. Persister cells, the biofilm matrix and tolerance to metal cations in biofilm and planktonic Pseudomonas aeruginosa. Environ. Microbiol. 7:981-994. https://doi.org/10.1111/j.1462-2920.2005.00777.x.

Hennekinne, J. A., M. L. De Buyser, and S. Dragacci. 2012. Staphylococcus aureus and its food poisoning toxins: Characterization and outbreak investigation. FEMS Microbiol. Rev. 36:815-836. https:/ /doi.org/10.1111/j.1574-6976.2011.00311.x.

Higginbotham, K. L., K. P. Burris, S. Zivanovic, P. M. Davidson, and C. N. Stewart Jr.. 2014. Antimicrobial activity of Hibiscus sabdariffa aqueous extracts against Escherichia coli O157:H7 and Staphylococcus aureus in a microbiological medium and milk of various fat concentrations. J. Food Prot. 77:262-268. https://doi .org/10.4315/0362-028X.JFP-13-313.

Jang, D. S., J. M. Kim, J. H. Kim, and J. S. Kim. 2005. 24-nor-ursane type triterpenoids from the stems of Rumex japonicus. Chem. Pharm. Bull. (Tokyo) 53:1594-1596. https://doi.org/10.1248/cpb .53 .1594

Johler, S., P. Giannini, M. Jermini, J. Hummerjohann, A. Baumgartner, and R. Stephan. 2015. Further evidence for staphylococcal food poisoning outbreaks caused by egc-encoded enterotoxin. Toxins (Basel) 7:997-1004. https://doi.org/10.3390/toxins7030997.

Jørgensen, H. J., T. Mathisen, A. Løvseth, K. Omoe, K. S. Qvale, and S. Loncarevic. 2005. An outbreak of staphylococcal food poisoning caused by enterotoxin $\mathrm{H}$ in mashed potato made with raw milk. FEMS Microbiol. Lett. 252:267-272. https://doi.org/10.1016/j .femsle.2005.09.005.

Kang, J. H., and K. B. Song. 2019. Antibacterial activity of the noni fruit extract against Listeria monocytogenes and its applicability as a natural sanitizer for the washing of fresh-cut produce. Food Microbiol. 84:103260. https://doi.org/10.1016/j.fm.2019.103260.

Kim, G., R. Y. Gan, D. Zhang, A. K. Farha, O. Habimana, V. Mavumengwana, H. B. Li, X. H. Wang, and H. Corke. 2020. Large-scale screening of 239 traditional Chinese medicinal plant extracts for their antibacterial activities against multidrug-resistant Staphylococcus aureus and cytotoxic activities. Pathogens 9:185. https:// doi.org/10.3390/pathogens9030185.

Kümmel, J., B. Stessl, M. Gonano, G. Walcher, O. Bereuter, M. Fricker, T. Grunert, M. Wagner, and M. Ehling-Schulz. 2016. Staphylococcus aureus entrance into the dairy chain: tracking $S$. aureus from dairy cow to cheese. Front. Microbiol. 7:1603. https://doi .org $/ 10.3389 /$ fmicb. 2016.01603.

Lee, S. H. I., B. L. C. Mangolin, J. L. Goncalves, D. V. Neeff, M. P. Silva, A. G. Cruz, and C. A. F. Oliveira. 2014. Biofilm-producing ability of Staphylococcus aureus isolates from Brazilian dairy farms. J. Dairy Sci. 97:1812-1816. https://doi.org/10.3168/jds .2013-7387.

Lister, J. L., and A. R. Horswill. 2014. Staphylococcus aureus biofilms: Recent developments in biofilm dispersal. Front. Cell. Infect. Microbiol. 4:178. https://doi.org/10.3389/fcimb.2014.00178.

Liu, X., H. Li, L. Wu, J. Xing, Y. Poh, H. Cai, and B. C. Cai. 2015. Simultaneous quantification of chrysophanol and physcion in rat plasma by ultra fast liquid chromatography-tandem mass spectrometry and application of the technique to comparative pharmacokinetic studies of Radix et Rhei Rhizoma extract alone and Dahuang Fuzi decoction. J. Chromatogr. B Analyt. Technol. Biomed. Life Sci. 980:88-93. https://doi.org/10.1016/j.jchromb.2014.11 .025 .

Ma, D. S. K., L. T. H. Tan, K. G. Chan, W. H. Yap, P. Pusparajah, L. H. Chuah, L. C. Ming, T. M. Khan, L. H. Lee, and B. H. Goh. 2018. Resveratrol-Potential antibacterial agent against foodborne pathogens. Front. Pharmacol. 9:102. https://doi.org/10 .3389/fphar.2018.00102.

Meroni, G., J. F. Soares Filipe, L. Drago, and P. A. Martino. 2019. Investigation on antibiotic-resistance, biofilm formation and virulence factors in multi drug resistant and non multi drug resistant Staphylococcus pseudintermedius. Microorganisms 7:702. https:// doi.org/10.3390/microorganisms7120702.

Munita, J. M., and C. A. Arias. 2016. Mechanisms of antibiotic resistance. Microbiol. Spectr. 4. https://doi.org/10.1128/microbiolspec .VMBF-0016-2015.

Nakano, H., K. K. Schrader, L. K. Mamonov, T. S. Kustova, V. K. Mursaliyeva, and C. L. Cantrell. 2012. Isolation and identification of Flavobacterium columnare and Streptococcus iniae antibacterial compounds from the terrestrial plant Atraphaxis laetevirens. J. Agric. Food Chem. 60:10415-10419. https://doi.org/10.1021/ jf304155n.

Nishina, A., K. Kubota, and T. Osawa. 1993. Antimicrobial components, trachrysone and 2-methoxystypandrone, in Rumex japonicus Houtt. J. Agric. Food Chem. 41:1772-1775. https://doi.org/ $10.1021 / \mathrm{jf00034a047}$

O'May, C., and N. Tufenkji. 2011. The swarming motility of Pseudomonas aeruginosa is blocked by cranberry proanthocyanidins and other tannin-containing materials. Appl. Environ. Microbiol. 77:3061-3067. https://doi.org/10.1128/AEM.02677-10.

Ogawara, H. 2019. Comparison of antibiotic resistance mechanisms in antibiotic-producing and pathogenic bacteria. Molecules 24:3430. https://doi.org/10.3390/molecules24193430.

Orbán-Gyapai, O., E. Liktor-Busa, N. Kúsz, D. Stefkó, E. Urbán, J. Hohmann, and A. Vasas. 2017. Antibacterial screening of Rumex species native to the Carpathian Basin and bioactivity-guided isolation of compounds from Rumex aquaticus. Fitoterapia 118:101106. https://doi.org/10.1016/j.fitote.2017.03.009.

Pollitt, E. J. G., and S. P. Diggle. 2017. Defining motility in the Staphylococci. Cell. Mol. Life Sci. 74:2943-2958. https://doi.org/ 10.1007/s00018-017-2507-z.

Rabin, N., Y. Zheng, C. Opoku-Temeng, Y. Du, E. Bonsu, and H. O. Sintim. 2015. Biofilm formation mechanisms and targets for devel- 
oping antibiofilm agents. Future Med. Chem. 7:493-512. https:// doi.org/10.4155/fmc.15.6.

Silva, L. N., K. R. Zimmer, A. J. Macedo, and D. S. Trentin. 2016. Plant natural products targeting bacterial virulence factors. Chem. Rev. 116:9162-9236. https://doi.org/10.1021/acs.chemrev $.6 \mathrm{~b} 00184$.

Sun, Y., G. B. Lenon, and A. W. H. Yang. 2020. Rumex japonicus Houtt: A phytochemical, pharmacological and pharmacokinetic review. Phytother. Res. 34:1198-1215. https://doi.org/10.1002/ ptr.6601.

Unlu, A., T. Sar, G. Seker, A. G. Erman, E. Kalpar, and M. Y. Akbas. 2018. Biofilm formation by Staphylococcus aureus strains and their control by selected phytochemicals. Int. J. Dairy Technol. 71:637-646. https://doi.org/10.1111/1471-0307.12520.

Upadhyay, N., A. Goyal, A. Kumar, D. K. Ghai, and R. Singh. 2014. Preservation of milk and milk products for analytical purposes. Food Rev. Int. 30:203-224. https://doi.org/10.1080/87559129.2014 .913292 .

Wang, J., H. Zhao, W. Kong, C. Jin, Y. Zhao, Y. Qu, and X. Xiao. 2010. Microcalorimetric assay on the antimicrobial property of five hydroxyanthraquinone derivatives in rhubarb (Rheum palmatum L.) to Bifidobacterium adolescentis. Phytomedicine 17:684-689. https://doi.org/10.1016/j.phymed.2009.10.009.

Wang, W., X. Lin, T. Jiang, Z. Peng, J. Xu, L. Yi, F. Li, S. Fanning, and Z. Baloch. 2018a. Prevalence and characterization of Staphylococcus aureus cultured from raw milk taken from dairy cows with mastitis in Beijing, China. Front. Microbiol. 9:1123. https://doi .org/10.3389/fmicb.2018.01123.

Wang, X., Y. Qin, G. Q. Li, S. Chen, J. Q. Ma, Y. L. Guo, and W. Z. Luo. 2018b. Study on chemical constituents in Polygoni cuspidati Folium and its preparation by UPLC-ESI-Q-TOF MS/MS. J. Chromatogr. Sci. 56:425-435. https://doi.org/10.1093/chromsci/ bmy017.
Xie, L., X. Liu, X. Zhu, Y. Xu, S. Peng, K. Sun, H. Cai, Q. Dai, C. Wang, Q. Zhou, and B. Cai. 2019. Development of an UHPLC-MS/MS method for comparative pharmacokinetics of nine anthraquinones in rats and application to dosage conversion between different Semen Cassiae forms. J. Pharm. Biomed. Anal. 174:696-706. https://doi.org/10.1016/j.jpba.2019.07.001.

XunLi, Y., S. Liu, S. Chu, Y. Yang, S. Peng, B. Ren, Wen, and N. Chen . 2019. Physcion and physcion 8-O- $\beta$-glucopyranoside: A review of their pharmacology, toxicities and pharmacokinetics. Chem. Biol. Interact. 310:108722. https://doi.org/10.1016/j.cbi .2019.06.035.

Zhang, D., R. Y. Gan, A. K. Farha, G. Kim, Q. Q. Yang, X. M. Shi, C. L. Shi, Q. X. Luo, X. B. Xu, H. B. Li, and H. Corke. 2019 Discovery of antibacterial dietary spices that target antibiotic-resistant bacteria. Microorganisms 7:157. https://doi.org/10.3390/ microorganisms7060157.

Zheng, Y., L. Chen, Y. Liu, L. Shi, S. Wan, and L. Wang. 2019. Evaluation of antimicrobial activity of water-soluble flavonoids extract from Vaccinium bracteatum Thunb. leaves. Food Sci. Biotechnol. 28:1853-1859. https://doi.org/10.1007/s10068-019-00634-4.

Zhu, H. L., G. Chen, S. N. Chen, R. Q. Wang, L. Chen, H. Xue, and S. P. Jian. 2020. Changes in cell membrane properties and phospholipid fatty acids of Bacillus subtilis induced by polyphenolic extract of Sanguisorba officinalis L. J. Food Sci. 85:2164-2170. https://doi.org/10.1111/1750-3841.15170.

\section{ORCIDS}

G. Kim ๑ https://orcid.org/0000-0001-7600-7485 